\title{
Ethereal Extract of Pepper: Preventing Atherosclerosis and Left Ventricle Remodeling in LDL Receptor Knockout Mice
}

\author{
Leandro dos Santos ${ }^{1}$, Letícia de Oliveira Maciel $^{2}$, Erika Kristina Incerpi Gracia ${ }^{3}$, Evelise Aline Soares ${ }^{3}$, \\ Danielle Aparecida Quintino Silva Sarto ${ }^{4}$, Valério Garrone Barauna ${ }^{5}$, Heder Frank Gianotto Estrela ${ }^{6}$, \\ Carollayne Mendonça Rocha ${ }^{7}$, Maria das Graças de Souza Carvalho ${ }^{8}$, Brígida Monteiro Vilas Boas", \\ and José Antônio Dias Garcia ${ }^{4,7,8}$
}

\author{
${ }^{1}$ Pernambuco Rural Federal University - Serra Talhada Academic Unit (UFRPE - UAST), Serra Talhada, PE 56909-535, Brazil \\ ${ }^{2}$ Federal Institute of Southern Minas Gerais (IFSULDEMINAS), Muzambinho, MG 37890-000, Brazil \\ ${ }^{3}$ Federal University of Alfenas (UNIFAL), Alfenas, MG 37130-000, Brazil \\ ${ }^{4}$ Postgraduate Program in Food Science and Technology, Federal Institute of Southern Minas Gerais (IFSULDEMINAS) - Campus Machado, \\ Machado, MG 37750-000, Brazil \\ ${ }^{5}$ Department of Physiological Sciences, Federal University of Espírito Santo (UFES), Vitória, ES 29075-910, Brazil \\ ${ }^{6}$ Department of Biology and Physiology, Jundiaí Medical School (FMJ), Jundiaí, SP 13202-550, Brazil \\ ${ }^{7}$ Department of Medicine, and ${ }^{8}$ Postgraduate Program in Reproduction Sanitation and Animal Welfare, \\ José do Rosário Vellano University (UNIFENAS), Alfenas, MG 37132-440, Brazil
}

\begin{abstract}
Cardiovascular diseases are the leading cause of mortality and morbidity worldwide. In this study we compared the effects of oral treatment with red pepper ethereal extracts or simvastatin on dyslipidemia, left ventricle remodeling, and atherosclerotic lesions of low-density lipoprotein (LDL) receptor knockout mice (LDLr ${ }^{-/}$) fed a hyperlipidic diet. Forty 3-month-old male mice were distributed into four groups: control (C; animals fed a standard diet), HL (animals fed a hyperlipidic diet), and $\mathrm{HL}+\mathrm{P}$ or $\mathrm{HL}+\mathrm{S}$ (animals fed a hyperlipidic diet plus red pepper ethereal extracts or simvastatin, respectively). After 60 days, treatment with both red pepper ethereal extracts and simvastatin prevented dyslipidemia, atherosclerotic lesion progression, and left ventricle hypertrophy. Our results suggest a cardioprotective effect of red pepper ethereal extracts in $\mathrm{LDLr}^{-/-}$mice, which is comparable to the well-known effects of simvastatin.
\end{abstract}

Keywords: atherosclerosis, inflammation, oxidative stress, red pepper, simvastatin

\section{INTRODUCTION}

Cardiovascular diseases (CVD) are a leading causes of mortality and morbidity in the world, despite the pharmaceutical industry's progress in producing new drugs against these diseases. Dyslipidemia represents an important risk factor for CVD (Yusuf et al., 2004). Primary or non-apparent dyslipidemias are classified into genotypes or phenotypes by biochemical analyzes. In the genotype classification, dyslipidemias are classified as monogenic, caused by mutations in unique genes, or polygenic, caused by multiple mutations that would not be of great repercussion alone. Phenotypic or biochemical classification considers the values of total cholesterol (TC), low- density lipoprotein cholesterol (LDLc), triglycerides (TG), and high-density lipoprotein cholesterol (HDLc), and comprises four main well defined types: isolated hypercholesterolemia, isolated hypertriglyceridemia, mixed hyperlipidemia, and low HDLc (Faludi et al., 2017).

Dyslipidemia is associated with oxidative stress, and its relationship with atherosclerotic coronary disease, left ventricular hypertrophy ( $\mathrm{LVH})$, and insulin resistance has been demonstrated in multiple studies (Madamanchi et al., 2005; Garcia et al., 2008; Gul'ašová et al., 2020). Interactions between lifestyle, environment, and genetics reflect the complex pathological process, in which oxidative stress caused by reactive oxygen species (ROS) plays a key role (Haslam and James, 2005). 
The reduction of morbimortality due to cardiovascular diseases through interruption, regression, and prevention of atherosclerotic disease and LVH by plasma cholesterol-lowering drugs has also been reported by numerous studies (Garcia et al., 2008; Baigent et al., 2011; Garcia et al., 2011). The reduction of LDLc by hydroxymethylglutaryl coenzyme A reductase inhibitors (statins), remain the most validated therapy in clinical studies to reduce the incidence of cardiovascular events (Xavier et al., 2013). However, long-term statin treatment is associated to skeletal muscle complaints, including myositis, rhabdomyolysis, serum creatine kinase increase, myalgia, and muscular weakness. An association of statins with several conditions, such as renal and hepatic compromising, hypothyroidism, diabetes, polyneuropathy, and other side effects, has been reported (Thompson et al., 2003; Ramkumar et al., 2016).

Peppers of the Capsicum genus belong to the Solanaceae family and comprise of more than 200 species, and are native to the humid tropical zones of Central and South America (Govindarajan, 1986). Several studies have shown that the genus Capsicum has a wide variety of phytotherapies with antioxidant properties, such as carotenoids (Deli et al., 2001), capsaicinoids (Pino et al., 2007), and phenolic compounds, including flavonoids, quercetin, and luteolin (Marín et al., 2004; Materska and Perucka, 2005; Kappel et al., 2008). Specifically, studies have shown the presence of compounds with antioxidant and anti-inflammatory activity in the Capsicum baccatum var. pendulum (Kappel et al., 2008; Kollmannsberger et al., 2011).

In 2017, our group published an article showing similar protective cardiovascular effects of soy milk and simvastatin (Santos et al., 2017). Therefore, the aim of the present study was to study the effects of red pepper ethereal extracts on dyslipidemia, cardiac remodeling, and atherosclerotic injury in $\mathrm{LDLr}^{-/-}$mice fed a hyperlipidic diet. Our results suggest that red pepper ethereal extracts induces cardiovascular protective effects in $\mathrm{LDLr}^{-/-}$mice similar to those induced by simvastatin treatment.

\section{MATERIALS AND METHODS}

\author{
Animals \\ Experiments were performed in homozygotic 3-month \\ age male $\mathrm{LDLr}^{-1-}$ mice generated from C57BL6/J (weight: \\ $22 \pm 3 \mathrm{~g}$ ). Mice were acquired from The Jackson Labora- \\ tory (Bar Harbor, ME, USA) and bred in the José do \\ Rosário Vellano University (UNIFENAS) Biotery (Alfe- \\ nas, MG, Brazil) with temperature controlled and a 12-h \\ light/dark cycle environment. $\mathrm{LDLr}^{-/-}$mice $(\mathrm{n}=10 /$ \\ group) were either fed a standard diet [Nuvital Nutrien- \\ tes S.A., Colombo, Paraná, Brazil; control group (C)], or
}

a hyperlipidic diet (HL group; $20 \%$ total fat with $70.25 \%$ coconut fat and $23.75 \%$ soy oil, $1.25 \%$ cholesterol, and $0.5 \%$ cholic acid), with water and food ad libitum. HL fed animals received water (vehicle), ethereal extract of red pepper (the Capsicum baccatum var. pendulum, $2 \mathrm{~g} / \mathrm{kg} ; \mathrm{HL}$ + P group), or simvastatin (Medley Farmacêutica, Campinas, SP, Brazil, $20 \mathrm{mg} / \mathrm{kg} / \mathrm{d}$; HL+S group) daily per gavage for 60 days. The peppers used in our study was cultivated at the Federal Institute of Southern Minas Gerais in the city of Muzambinho, MG, Brazil. Red pepper ethereal extracts were supplied by the Laboratory of Bromatology of the Federal Institute of Southern Minas Gerais. Physicochemical analysis was carried out to analyze the moisture content and presence of ash, lipids, proteins, and carbohydrates in the peppers. The moisture content was obtained by drying in an oven at $105^{\circ} \mathrm{C}$; the percentage of ash was obtained by heating to $550^{\circ} \mathrm{C}$; the amount of crude protein was calculated by the Kjeldahl method, adopting the correction factor of 6.25. All analyses were performed according to the methodology described by Pregnolatto and Pascuet (1985).

The Bligh and Dyer technique was used to analyze the total lipids content (Bligh and Dyer, 1959). Analysis of total phenolic content was carried out at the Agricultural Research Company of Minas Gerais (EPAMIG) in Caldas, MG, Brazil, using the Folin-Ciocalteau method with gallic acid as the reference standard (Lowry et al., 1951). All analyses were conducted in triplicate. Experimental procedures were performed in accordance with the guidelines established by the National Council for Animal Experiments Control (CONCEA) and were approved by the Animals Ethics Committee of the Federal Institute of South Minas Gerais (registered at no. 03A/2014).

Blood sample was obtained by retro-orbital venous plexus puncture in anesthetized animals (xylazine/ketamine, $6 / 40 \mathrm{mg} / \mathrm{kg}$, respectively; Parke-Davis \& Co., Detroit, MI, USA) for analysis of glucose, insulin, TG, TC, and HDLc serum fractions. After subsequent thoracotomy, hearts and aorta were perfused in situ with $1.34 \mathrm{mM}$ $\mathrm{KCl}$ followed by $10 \%$ phosphate buffered saline (PBS)buffered formaldehyde. The hearts were then removed and left ventricles (LV) were isolated. The LV weight (mg)/body weight (g) ratio was used as the LVH index. LVs and thoracic aortas were fixed for $24 \mathrm{~h}$ in $10 \%$ formaldehyde.

\section{Serum analysis}

Serum was obtained by centrifugation of blood samples $\left(1,200 \mathrm{~g}, 4^{\circ} \mathrm{C}\right.$, and $\left.10 \mathrm{~min}\right)$. Glucose serum levels were measured using a colorimetric enzymatic method. Insulin serum levels was determined using commercial enzymelinked immunosorbent assay kits (DAKO Ltd., High Wycombe, Bucks, UK). Homeostatic model assessment (HOMA) indexes [HOMA-insulin resistance (IR)] were 
calculated using the following formula: HOMA-IR $=[$ ffast insulinemia $(\mathrm{mU} / \mathrm{L}) \times$ fast glycemia $(\mathrm{mmol} / \mathrm{L})\} / 22.5$ ] to determine insulin resistance. Enzymatic trials were used to measure TG, TC, and HDLc, as described by Hedrick et al. (2001).

\section{Determination of LDLc and VLDLc}

LDLc was determined according to the formula described by Friedewald et al. (1972): LDLc (mg/dL) $=$ TC - HDLc $-\mathrm{TG} / 5.0$. VLDLc was determined according to the formula described by Tian et al. (2006): VLDLc (mg/dL) $=$ TG/5.0.

\section{Measurement of superoxide anion levels in aortas}

Superoxide anion levels were assessed in thoracic aortic homogenates by using lucigenin $(5 \mu \mathrm{mol} / \mathrm{L})$ chemiluminescence, as described by Laurindo et al. (2002). Results were expressed as counts per min $(\mathrm{cpm}) / \mathrm{mg}$ protein, quantified by the Bradford method.

\section{Histological analysis}

Hearts were sequentially embedded in 5,10 , and $25 \%$ gelatin. Oil red staining was performed in aortic roots according to Paigen et al. (1987), and blind quantified as previously described (Krieger et al., 2006) using Image Pro Plus software (version 3.0) for image analysis (Media Cybernetics, Inc., Rockville, MD, USA).

For morphometric analyses of cardiomyocyte diameters and collagen deposition, $4 \mu \mathrm{m}$-width sections from LVs embedded in paraffin were stained with hematoxylin-eosin and picrosirius red, respectively. Photomicrographs were taken from the same prefixed point of LV cross sections of each mouse using a digital camera coupled to a Leica IM50 (Leica Camera AG, Wetzlar, Germany). Cardiomyocyte diameters of 8 to 12 cells were measured in each section per animal (Armstrong et al., 1998). Picrosirius red stained sections were subjected to a polarized light, and each photomicrograph was analyzed using LGMC-image software (Lafayette General Medical Center,
USA) (Shirani et al., 2000).

\section{Immunohistochemistry}

LV and abdominal aorta histological sections were treated with $3 \%$ hydrogen peroxide to block endogenous peroxidase activity. Nonspecific sites were blocked with $2 \%$ skimmed milk diluted in phosphate-buffered saline (10 $\mathrm{mM}$ PBS, $\mathrm{pH}=7.4$ ). Glass slides containing tissue sections were incubated for $12 \mathrm{~h}$ in a humid chamber at $4^{\circ} \mathrm{C}$ with polyclonal anti-CD40L antibodies (1:50, Santa Cruz Biotechnology, Inc., Santa Cruz, CA, USA). Sections were then washed with PBS and incubated with a biotinylated secondary antibodies (Dako Denmark A/S, Glostrup, Denmark) in a humid chamber for $1 \mathrm{~h}$ at $37^{\circ} \mathrm{C}$. In order to visualize immunoreactive areas, glass slides were incubated with conjugate complexes with peroxidase (Dako Denmark A/S) for $45 \mathrm{~min}$ at $37^{\circ} \mathrm{C}$, and incubated in a chromogenic solution $(50 \mathrm{mg}$ diaminobenzidine in $50 \mathrm{~mL}$ PBS with $3 \mathrm{~mL} 10 \%$ oxygen water) for $3 \mathrm{~min}$. After counterstaining with Harris hematoxylin (Sigma-Aldrich Co., St. Louis, MO, USA) for $25 \mathrm{~s}$, glass slides were mounted and analyzed by optical microscopy. Photomicrographs were analyzed by LGMC-image software (Garcia et al., 2008).

\section{Statistical analyses}

Data are expressed as mean \pm standard error of the mean (SEM). Differences between means were compared by using one-way analyses of variance (ANOVA) followed by Tukey's post-hoc test. Differences were considered significant at $P<0.05$ level.

\section{RESULTS}

In the present study, pepper ethereal extract had an average total phenolic concentration of $0.034 \pm 0.007 \mathrm{mg} / \mathrm{g}$, and an average humidity of $79.90 \pm 0.41$. The percentages of moisture, ash, lipids, proteins, and carbohydrates were

Table 1. Effects of red pepper ethereal extract and simvastatin on serum triglycerides, cholesterol fractions, glucose, and insulin in $\mathrm{LDLr}^{-/-}$mice fed with a hyperlipidic diet

\begin{tabular}{|c|c|c|c|c|}
\hline Groups & C & $\mathrm{HL}$ & $\mathrm{HL}+\mathrm{P}$ & $\mathrm{HL}+\mathrm{S}$ \\
\hline $\mathrm{TC}(\mathrm{mg} / \mathrm{dL})$ & $222 \pm 18$ & $685 \pm 36^{* 1 \neq}$ & $424 \pm 30^{* \# \#}$ & $328 \pm 31^{* \# \dagger}$ \\
\hline LDLc (mg/dL) & $139.8 \pm 7.0$ & $613.6 \pm 34.0^{* t \neq}$ & $338.4 \pm 28.6^{\text {*\# }}$ & $259.0 \pm 31.2^{* \# 1}$ \\
\hline $\operatorname{VLDLc}(\mathrm{mg} / \mathrm{dL})$ & $24.2 \pm 1.0$ & $46.4 \pm 1.5^{* \dagger \ddagger}$ & $34.6 \pm 0.8^{* \#}$ & $31 \pm 1.5^{* \#}$ \\
\hline HDLc (mg/dL) & $58 \pm 2$ & $25 \pm 3^{* \dagger}$ & $51 \pm 8^{\# \neq}$ & $38 \pm 2^{* \# \dagger}$ \\
\hline $\mathrm{TG}(\mathrm{mg} / \mathrm{dL})$ & $122 \pm 5$ & $232 \pm 6^{* 1 \neq}$ & $173 \pm 5^{* \# \neq}$ & $155 \pm 6^{* \#+}$ \\
\hline Glucose (mmol/L) & $5.4 \pm 0.1$ & $5.4 \pm 0.2$ & $5.5 \pm 0.2$ & $5.1 \pm 0.1$ \\
\hline Insulin (mU/mL) & $2.8 \pm 0.1$ & $5.7 \pm 0.6^{* \dagger \neq}$ & $3.7 \pm 0.2^{* \#}$ & $3.1 \pm 0.2^{\#}$ \\
\hline HOMA-IR & $0.7 \pm 0.1$ & $1.4 \pm 0.2^{* \dagger \ddagger}$ & $0.9 \pm 0.1^{* \#}$ & $0.7 \pm 0.1^{\#}$ \\
\hline
\end{tabular}

Values are mean \pm SEM $(n=10)$.

$\mathrm{C}$, control group; $\mathrm{HL}$, hyperlipidic diet-fed group; $\mathrm{HL}+\mathrm{P}$, hyperlipidic diet-fed group treated with ethereal extract of red pepper; $\mathrm{HL}+\mathrm{S}$, hyperlipidic diet-fed group treated with simvastatin; TC, total cholesterol; TG, triacylglycerol.

${ }^{*} P<0.05$ vs $C,{ }^{\sharp} P<0.05$ vs $\mathrm{HL},{ }^{\dagger} P<0.05$ vs $\mathrm{HL}+\mathrm{P}$, and ${ }^{\ddagger} P<0.05$ vs $\mathrm{HL}+\mathrm{S}$ (two-way ANOVA). 
$4.10 \pm 0.03,1.00 \pm 0.09,3.50 \pm 0.05$, and $11.60 \pm 0.08$, respectively (data not shown).

Serum biochemistry profiles of each group are shown in Table 1. The HL group exhibited severe dyslipidemia compared with the $\mathrm{C}$ group, shown by an increase in serum TG and TC. In addition, the HL group exhibited a marked decrease in the HDLc fraction and marked increases in the LDLc and VLDLc fractions compared with the $\mathrm{C}$ group. The red pepper ethereal extracts and simvastatin both prevented increases in TG, TC, LDLc, and VLDc, and the decrease in HDLc. However, the red pepper ethereal extract was more effective than simvastatin in preventing decreases in HDLc caused by the hyperlipidic diet. However, there were no differences in serum glucose levels among groups. Moreover, the HL group showed increased insulinemia compared with the $\mathrm{C}$ group, with increased HOMA-IR. These changes were partially prevented in the $\mathrm{HL}+\mathrm{P}$ group, and completely prevented in the $\mathrm{HL}+\mathrm{S}$ group. There were no significant differences in body weight among groups (C: $23.0 \pm 2.0$ g; HL: $23.3 \pm$ 1.8 g; HL+P: $23.4 \pm 1.6$ g; HL+S: $23.6 \pm 1.7$ g, data not shown).

Both the red pepper ethereal extracts and simvastatin prevented the increase in insulin resistance; the increase in insulin resistance was completely prevented by simvastatin but only partially prevented by red pepper ethereal extracts (Table 1).

Aorta of mice from the HL group exhibited increased superoxide anion levels compared with the $\mathrm{C}$ group. In addition, aorta of mice from the HL group exhibited

Table 2. Aortic and left ventricle (LV) parameters

\begin{tabular}{|c|c|c|c|c|}
\hline Groups & $\mathrm{C}$ & $\mathrm{HL}$ & $\mathrm{HL}+\mathrm{P}$ & $\mathrm{HL}+\mathrm{S}$ \\
\hline \multicolumn{5}{|l|}{ Aorta } \\
\hline CD40L (\%) & $2.1 \pm 0.2$ & $8.8 \pm 0.7^{* \ddagger}$ & $4.1 \pm 0.4^{* \#}$ & $3.8 \pm 0.3^{* \#}$ \\
\hline Superoxide anion (cpm $\times 10^{6} / \mathrm{mg}$ protein) & $6.9 \pm 1.1$ & $14.0 \pm 1.8^{* \dagger}$ & $8.0 \pm 2.2^{\#}$ & $6.2 \pm 1.6^{\#}$ \\
\hline Atheroma plaque's area $\left(\mu \mathrm{m}^{2}\right)$ & $23 \pm 5$ & $5,567 \pm 1,443^{* \dagger \ddagger}$ & $1,498 \pm 417^{* \#}$ & $1,590 \pm 358^{* \#}$ \\
\hline \multicolumn{5}{|l|}{ LV } \\
\hline Cardiomyocytes diameter $(\mu \mathrm{m})$ & $16 \pm 1$ & $26 \pm 1^{* \dagger \ddagger}$ & $20 \pm 1^{* \#}$ & $18 \pm 1^{\#}$ \\
\hline Collagen $(\%)$ & $4.7 \pm 0.4$ & $11.3 \pm 0.6^{* \dagger \ddagger}$ & $4.2 \pm 0.1^{\#}$ & $4.3 \pm 0.5^{\#}$ \\
\hline LV weight (mg)/body weight (g) & $3.3 \pm 0.0$ & $4.1 \pm 0.1^{* \dagger \ddagger}$ & $3.4 \pm 0.1^{\#}$ & $3.3 \pm 0.1^{\#}$ \\
\hline CD4OL (\%) & $1.3 \pm 0.2$ & $5.9 \pm 0.4^{* \dagger \neq}$ & $3.0 \pm 0.3^{* \#}$ & $3.3 \pm 0.4^{* \#}$ \\
\hline
\end{tabular}

Values are mean \pm SEM $(n=10)$.

C, control group; $\mathrm{HL}$, hyperlipidic diet-fed group; $\mathrm{HL}+\mathrm{P}$, hyperlipidic diet-fed group treated with ethereal extract of red pepper; $\mathrm{HL}+\mathrm{S}$, hyperlipidic diet-fed group treated with simvastatin.

${ }^{*} P<0.05$ vs $\mathrm{C} ;{ }^{\#} P<0.05$ vs $\mathrm{HL} ;{ }^{\dagger} P<0.05$ vs $\mathrm{HL}+\mathrm{P} ;{ }^{\ddagger} P<0.05$ vs $\mathrm{HL}+\mathrm{S}$ (two-way ANOVA).

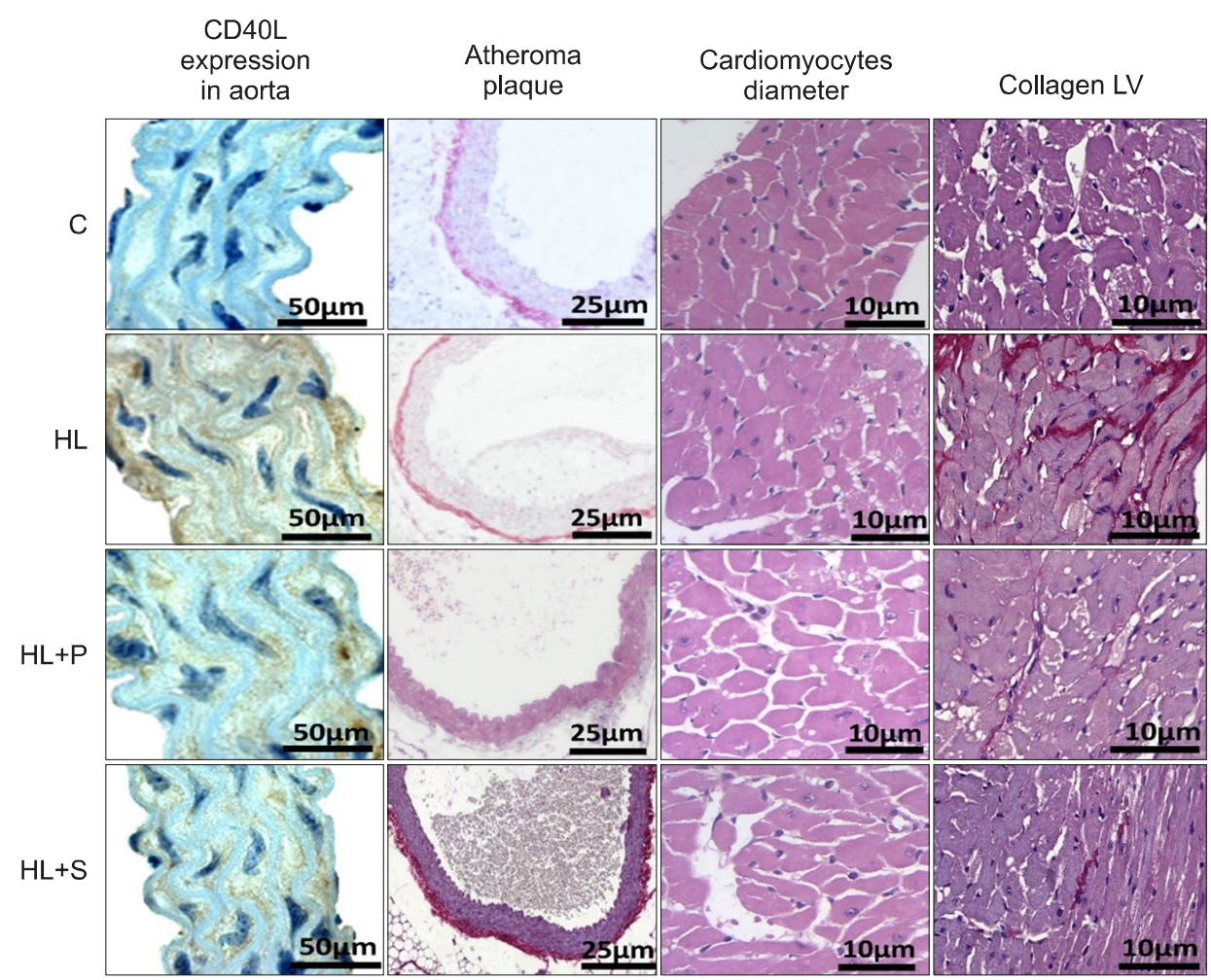

Fig. 1. Photomicrographs of aorta and left ventricles (LV). Expression of CD40L in aorta and hematoxylin and eosin (HE) staining of atheromatous plaques in the left ventricles, showing the diameter of the cardiomyocytes, stained with HE. Photomicrographs showing the distribution of interstitial and perivascular staining with red collagen (marked in red by the dye) in the left ventricular myocardium of mice stained with picrosirius. C, control group; $\mathrm{HL}$, hyperlipidic diet-fed group; $\mathrm{HL}+$ $P$, hyperlipidic diet-fed group treated with ethereal extract of red pepper; $\mathrm{HL}+\mathrm{S}$, hyperlipidic diet-fed group treated with simvastatin. 
greater CD40L-immunoreactive and plaque areas compared with aortas from mice in the $\mathrm{C}$ group. These alterations in aorta tissue were prevents to a similar extent by red pepper ethereal extracts and simvastatin (Table 2 and Fig. 1).

The HL group developed cardiac hypertrophy, as demonstrated by a $38 \%$ increase in cardiomyocyte diameters and a $24 \%$ increase in LV weight/body weight ratios, and fibrosis, as demonstrated by a $140 \%$ increase in the collagen fraction compared with the $\mathrm{C}$ group. Treatment with simvastatin completely prevented the increase in cardiomyocyte diameter, whereas it was only partially prevented by red pepper ethereal extracts. However, both simvastatin and red pepper ethereal extracts prevented the collagen deposition. Furthermore, the LV weight (mg)/body weight (g) ratio and the CD40L-immunoreactive area in LV were similar between mice treated with both simvastatin and red pepper ethereal extracts and the HL group (Table 2 and Fig. 1).

\section{DISCUSSION}

Previous studies by our group have shown that severe dyslipidemia triggered by a high cholesterol diet is the main factor associated with arterial oxidative stress, acceleration of atherosclerotic plaque development, and ventricular hypertrophy in $\mathrm{LDLr}^{-1-}$ mice (Krieger et al., 2006; Santos et al., 2017). The HL diet induces increases in the area of CD40L immunoreactivity, indicating aggravation of the inflammatory response, which is an important risk factor for worsening atherosclerosis (Garcia et al., 2011). In addition, previous studies have demonstrated increases in the production of superoxide anions in the aortas and hearts in $\mathrm{LDLr}^{-/-}$mice fed the HL diet (Krieger et al., 2006; Garcia et al., 2008; Santos et al., 2017).

Oxidative stress induced by the HL diet decreases the bioavailability of nitric oxide, an important vasodilator and antithrombotic factor (Verma et al., 2002; Krieger et al., 2006). Furthermore, it leads to peroxidation of HDLc (Barter et al., 2004) and is protects cardiovascular function, by exhibiting antioxidant and anti-inflammatory activity. In addition, the proinflammatory framework, oxidative stress, and hyperinsulinemia favors remodeling of the LV, characterized by hypertrophy and myocardial fibrosis (Garcia et al., 2011), and accelerates progression of atherosclerotic disease (Krieger et al., 2006; Madonna and De Caterina, 2012).

The association between insulin resistance and oxidative stress, and the inflammatory response has been well established. In our study, mice fed the HL diet showed increased serum insulin levels. A previous study demonstrated increased insulin and TC secretion in $\mathrm{LDLr}^{-1-}$ mice fed a high fat diet, associated with hyperglycemia and decreased glucose tolerance (d Oliveira et al., 2014). Interestingly, there was no differences in glycemia between groups in the present study. The differing compositions of the hyperlipidic diet used in the previous study (d Oliveira et al., 2014) and our study may be responsible for the non-glycemic variation. Oxidative stress and inflammatory factors [such as tumor necrosis factor (TNF)- $\alpha$ ] induce activation of serine/threonine kinases that phosphorylate insulin receptor substrate 1 in serine, inhibiting its ability to activate phosphoinositide 3-kinases/Akt and stimulate signaling via mitogen-activated protein kinase (Sykiotis and Papavassiliou, 2001). Decreased insulin sensitivity accompanied by a compensatory increase in insulin secretion represents additional overload on pancreatic- $\beta$ cells. Insulin resistance in adipocytes leads to increased intracellular hydrolysis of TG and release of fatty acids into the circulation (Ginsberg, 2000).

The novelty in this study concerns the protective cardiovascular role of red pepper (Capsicum Baccatum var. pendulum) ethereal extracts. The hypolipidemic effects observed in the $\mathrm{HC}+\mathrm{P}$ group are in agreement with previous data, showing hamsters treated with capsaicinoids had reductions in TC, TG, and LDL, and decreased atherosclerotic plaques compared with the untreated control group (Liang et al., 2013). In addition, supplementation with red pepper increased fecal excretion of TG in hypercholesterolemic rabbits, and attenuated atherosclerosis and cholesterol ester transfer protein (CETP) activity (Kwon et al., 2003).

Zimmer et al. (2012) demonstrated that red pepper ethereal extracts had anti-inflammatory properties correlated with highest amount of phenolic compounds and flavonoids, as well as high amount of capsaicin and high antioxidant activity compared with other Capsicum species. These differences may be attributed to the botanical variety, maturity of the plant, extraction methods, and geographical origins of the plants. Accordingly, in the present study, the use of red pepper ethereal extracts significantly attenuated the oxidative stress present in the aortas of $\mathrm{LDLr}^{-/-}$mice fed a hyperlipidic diet. The protective effect of the extracts was similar to the effect of simvastatin, reinforcing its antioxidant potential in the cardiovascular system under severe dyslipidemia.

In the present study, red pepper ethereal extracts effectively prevented inflammation in the cardiovascular system, indicated by a smaller area of immunoreactivity for CD40L in the aorta and the LV compared with the HL group. Interestingly, red pepper ethereal extracts were more effective at increasing serum HDL levels than simvastatin. The mechanism associated with this effect has not yet been elucidated, and requires studies investigating the extract in pathways stimulating apo AI synthesis, 
in inhibition of CETP synthesis, and as a substrate for exchanging triglycerides by cholesterol ester via CETP.

Studies have shown that HDL can suppress transcription of molecules involved in cellular adhesion, such as CD11b/CD18, E-selectin, vascular cell adhesion molecule 1, and intercellular adhesion molecule 1 (ICAM-1) (Clay et al., 2001), decreases production of cytokines and chemokines such as TNF- $\alpha$, interleukin (IL)-6, IL-10, and monocyte chemoattractant protein- 1 (Kleemann et al., 2008), and inhibit activation of activator protein 1 and nuclear factor (NF)- $\mathrm{kB}$ (Park et al., 2003). Thus, preventing decreases in HDL levels induced by red pepper ethereal extracts may be related to the anti-inflammatory effect of these foods, as evidenced by the decrease in immunoreactivity for CD40L inflammatory markers in the aorta and the LV.

Simvastatin also prevented lipid profile changes, hyperinsulinemia, LVH, and changes in atheroma plaque areas induced by the hyperlipidic diet. These metabolic and cardiovascular effects may be related to antioxidant and anti-inflammatory responses in the LV and aorta, as demonstrated by the reduced size of the CD40L immunoreactivity area and reduced superoxide anion production. By reducing mevalonate and isoprenyl radical formation, statins attenuate activation of inflammatory molecules, such as ICAM-1, NF-kB, and CD40L (Sposito and Chapman, 2002). Statins also reduce ROS generation by vascular nicotinamide adenine dinucleotide phosphate hydrate-oxidase and may have a direct anti-inflammatory effect on eliminating free radicals, thereby contributing to increased synthesis of the vasodilatory and anti-thrombotic factor nitric oxide (Beltowski, 2005).

In conclusion, red pepper ethereal extracts showed beneficial metabolic and cardiovascular activity in preventing severe dyslipidemia, IR, atherosclerotic lesions, and cardiac remodeling in $\mathrm{LDLr}^{-/-}$mice fed a hyperlipidic diet. These protective effects were quantitatively comparable to the effects of simvastatin, and were associated with an improved redox balance and reduction of the systemic and cardiovascular inflammatory factor (CD40L). Our study suggests that the cardioprotective effect of red pepper ethereal extracts is due to the presence of phenolic compounds, mainly capsaicinoids, which exhibit anti-inflammatory and antioxidant activity (Ahuja et al., 2006; Liang et al., 2013). Thus, our study contributes to the literature by emphasizing the potential role of natural products in preventing dyslipidemia, atherogenesis, cardiovascular remodeling and insulin resistance. Furthermore, we showed that red pepper ethereal extract exhibit cardioprotective effects similar to the well-known effects of simvastatin.

\section{ACKNOWLEDGEMENTS}

This work was financial supported by $\mathrm{CNPq}$ and FAPEMIG.

\section{AUTHOR DISCLOSURE STATEMENT}

The authors declare no conflict of interest.

\section{REFERENCES}

Ahuja KD, Kunde DA, Ball MJ, Geraghty DP. Effects of capsaicin, dihydrocapsaicin, and curcumin on copper-induced oxidation of human serum lipids. J Agric Food Chem. 2006. 54:64366439.

Armstrong AT, Binkley PF, Baker PB, Myerowitz PD, Leier CV. Quantitative investigation of cardiomyocyte hypertrophy and myocardial fibrosis over 6 years after cardiac transplantation. J Am Coll Cardiol. 1998. 32:704-710.

Baigent C, Landray MJ, Reith C, Emberson J, Wheeler DC, Tomson $\mathrm{C}$, et al. The effects of lowering LDL cholesterol with simvastatin plus ezetimibe in patients with chronic kidney disease (Study of Heart and Renal Protection): a randomised placebocontrolled trial. Lancet. 2011. 377:2181-2192.

Barter PJ, Nicholls S, Rye KA, Anantharamaiah GM, Navab M, Fogelman AM. Antiinflammatory properties of HDL. Circ Res. 2004. 95:764-772.

Beltowski J. Statins and modulation of oxidative stress. Toxicol Mech Methods. 2005. 15:61-92.

Bligh EG, Dyer WJ. A rapid method of total lipid extraction and purification. Can J Biochem Physiol. 1959. 37:911-917.

Clay MA, Pyle DH, Rye KA, Vadas MA, Gamble JR, Barter PJ. Time sequence of the inhibition of endothelial adhesion molecule expression by reconstituted high density lipoproteins. Atherosclerosis. 2001. 157:23-29.

d Oliveira RB, Carvalho CP, Polo CC, de Dorighello G, Boschero AC, d Oliveira HC, et al. Impaired compensatory beta-cell function and growth in response to high-fat diet in LDL receptor knockout mice. Int J Exp Pathol. 2014. 95:296-308.

Deli J, Molnár P, Matus Z, Tóth G. Carotenoid composition in the fruits of red paprika (Capsicum annuum var. lycopersiciforme rubrum) during ripening; biosynthesis of carotenoids in red paprika. J Agric Food Chem. 2001. 49:1517-1523.

Faludi AA, Izar MCO, Saraiva JFK, Chacra APM, Bianco HT, Afiune Neto A, et al. Update of the Brazilian dyslipidemia and atherosclerosis prevention directive-2017. Arq Bras Cardiol. 2017. 109:1-76.

Friedewald WT, Levy RI, Fredrickson DS. Estimation of the concentration of low-density lipoprotein cholesterol in plasma, without use of the preparative ultracentrifuge. Clin Chem. 1972. 18:499-502.

Garcia JAD, de Lima CC, Messora LB, Cruz AF, Marques APS, Simão TP, et al. Anti-inflammatory effect of high-density lipoprotein on the cardiovascular system of hyperlipidemic mice. Rev Port Cardiol. 2011. 30:763-769.

Garcia JAD, dos Santos L, Moura AL, Ricardo KFS, Wanschel ACBA, Shishido SM, et al. S-nitroso- $N$-acetylcysteine (SNAC) prevents myocardial alterations in hypercholesterolemic LDL receptor knockout mice by antiinflammatory action. J Cardiovasc Pharmacol. 2008. 51:78-85.

Ginsberg HN. Insulin resistance and cardiovascular disease. J Clin Invest. 2000. 106:453-458. 
Govindarajan VS. Capsicum - production, technology, chemistry, and quality - Part II. Processed products, standards, world production and trade. Crit Rev Food Sci Nutr. 1986. 23:207-288.

Gul'ašová Z, Guerreiro SG, Link R, Soares R, Tomečková V. Tackling endothelium remodeling in cardiovascular disease. J Cell Biochem. 2020. 121:938-945.

Haslam DW, James WPT. Obesity. Lancet. 2005. 366:1197-1209.

Hedrick CC, Castellani LW, Wong $\mathrm{H}$, Lusis AJ. In vivo interactions of apoA-II, apoA-I, and hepatic lipase contributing to HDL structure and antiatherogenic functions. J Lipid Res. 2001. 42: 563-570.

Kappel VD, Costa GM, Scola G, Silva FA, Landell MF, Valente P, et al. Phenolic content and antioxidant and antimicrobial properties of fruits of Capsicum baccatum L. var. pendulum at different maturity stages. J Med Food. 2008. 11:267-274.

Kleemann R, Zadelaar S, Kooistra T. Cytokines and atherosclerosis: a comprehensive review of studies in mice. Cardiovasc Res. 2008. 79:360-376.

Kollmannsberger H, Rodríguez-Burruezo A, Nitz S, Nuez F. Volatile and capsaicinoid composition of ají (Capsicum baccatum) and rocoto (Capsicum pubescens), two Andean species of chile peppers. J Sci Food Agric. 2011. 91:1598-1611.

Krieger MH, Santos KF, Shishido SM, Wanschel AC, Estrela HF, Santos L, et al. Antiatherogenic effects of $S$-nitroso- $N$-acetylcysteine in hypercholesterolemic LDL receptor knockout mice. Nitric Oxide. 2006. 14:12-20.

Kwon MJ, Song YS, Choi MS, Song YO. Red pepper attenuates cholesteryl ester transfer protein activity and atherosclerosis in cholesterol-fed rabbits. Clin Chim Acta. 2003. 332:37-44.

Laurindo FRM, de Souza HP, de A Pedro M, Janiszewski M. Redox aspects of vascular response to injury. Methods Enzymol. 2002. 352:432-454

Liang YT, Tian XY, Chen JN, Peng C, Ma KY, Zuo Y, et al. Capsaicinoids lower plasma cholesterol and improve endothelial function in hamsters. Eur J Nutr. 2013. 52:379-388.

Lowry OH, Rosebrough NJ, Farr AL, Randall RJ. Protein measurement with the Folin phenol reagent. J Biol Chem. 1951. 193:265-275.

Madamanchi NR, Vendrov A, Runge MS. Oxidative stress and vascular disease. Arterioscler Thromb Vasc Biol. 2005. 25:2938.

Madonna R, De Caterina R. Atherogenesis and diabetes: focus on insulin resistance and hyperinsulinemia. Rev Esp Cardiol. 2012. 65:309-313.

Marín A, Ferreres F, Tomás-Barberán FA, Gil MI. Characterization and quantitation of antioxidant constituents of sweet pepper (Capsicum annuum L.). J Agric Food Chem. 2004. 52:3861-3869.

Materska M, Perucka I. Antioxidant activity of the main phenolic compounds isolated from hot pepper fruit (Capsicum annuum L). J Agric Food Chem. 2005. 53:1750-1756.

Paigen B, Morrow A, Holmes PA, Mitchell D, Williams RA. Quantitative assessment of atherosclerotic lesions in mice. Atherosclerosis. 1987. 68:231-240.
Park SH, Park JH, Kang JS, Kang YH. Involvement of transcription factors in plasma HDL protection against TNF- $\alpha$-induced vascular cell adhesion molecule-1 expression. Int J Biochem Cell Biol. 2003. 35:168-182.

Pino J, González M, Ceballos L, Centurión-Yah AR, TrujilloAguirre J, Latournerie-Moreno L, et al. Characterization of total capsaicinoids, colour and volatile compounds of Habanero chilli pepper (Capsicum chinense Jack.) cultivars grown in Yucatan. Food Chem. 2007. 104:1682-1686.

Pregnolatto W, Pascuet NS. Métodos físico-químicos para análise de alimentos. 3rd ed. Instituto Adolfo Lutz, São Paulo, Brazil. 1985. p 85-522.

Ramkumar S, Raghunath A, Raghunath S. Statin therapy: review of safety and potential side effects. Acta Cardiol Sin. 2016. 32: 631-639.

Santos L, Davel AP, Almeida TI, Almeida MR, Soares EA, Fernandes GJ, et al. Soy milk versus simvastatin for preventing atherosclerosis and left ventricle remodeling in LDL receptor knockout mice. Braz J Med Biol Res. 2017. 50:e5854. https:// doi.org/10.1590/1414-431x20165854

Shirani J, Pick R, Roberts WC, Maron BJ. Morphology and significance of the left ventricular collagen network in young patients with hypertrophic cardiomyopathy and sudden cardiac death. J Am Coll Cardiol. 2000. 35:36-44.

Sposito AC, Chapman MJ. Statin therapy in acute coronary syndromes: mechanistic insight into clinical benefit. Arterioscler Thromb Vasc Biol. 2002. 22:1524-1534.

Sykiotis GP, Papavassiliou AG. Serine phosphorylation of insulin receptor substrate-1: a novel target for the reversal of insulin resistance. Mol Endocrinol. 2001. 15:1864-1869.

Thompson PD, Clarkson P, Karas RH. Statin-associated myopathy. JAMA. 2003. 289:1681-1690.

Tian J, Pei H, Sanders JM, Angle JF, Sarembock IJ, Matsumoto $\mathrm{AH}$, et al. Hyperlipidemia is a major determinant of neointimal formation in LDL receptor-deficient mice. Biochem Biophys Res Commun. 2006. 345:1004-1009.

Verma S, Wang CH, Li SH, Dumont AS, Fedak PW, Badiwala MV, et al. A self-fulfilling prophecy: C-reactive protein attenuates nitric oxide production and inhibits angiogenesis. Circulation. 2002. 106:913-919.

Xavier HT, Izar MC, Faria Neto JR, Assad MH, Rocha VZ, Sposito AC, et al. V. Brazilian guidelines on dyslipidemias and prevention of atherosclerosis. Arq Bras Cardiol. 2013. 1:1-20.

Yusuf S, Hawken S, Ounpuu S, Dans T, Avezum A, Lanas F, et al.; INTERHEART Study Investigators. Effect of potentially modifiable risk factors associated with myocardial infarction in 52 countries (the INTERHEART study): case-control study. Lancet. 2004. 364:937-952.

Zimmer AR, Leonardi B, Miron D, Schapoval E, de Oliveira JR, Gosmann G. Antioxidant and anti-inflammatory properties of Capsicum baccatum: from traditional use to scientific approach. J Ethnopharmacol. 2012. 139:228-233. 